Customization or Conformity? An Institutional and Network Perspective on the Content and Consequences of TQM Adoption

Author(s): James D. Westphal, Ranjay Gulati and Stephen M. Shortell

Source: Administrative Science Quarterly, Vol. 42, No. 2 (Jun., 1997), pp. 366-394

Published by: Sage Publications, Inc. on behalf of the Johnson Graduate School of Management, Cornell University

Stable URL: http://www.jstor.org/stable/2393924

Accessed: 27-02-2015 17:36 UTC

Your use of the JSTOR archive indicates your acceptance of the Terms \& Conditions of Use, available at http://www.jstor.org/page/info/about/policies/terms.jsp

JSTOR is a not-for-profit service that helps scholars, researchers, and students discover, use, and build upon a wide range of content in a trusted digital archive. We use information technology and tools to increase productivity and facilitate new forms of scholarship. For more information about JSTOR, please contact support@jstor.org.

Sage Publications, Inc. and Johnson Graduate School of Management, Cornell University are collaborating with JSTOR to digitize, preserve and extend access to Administrative Science Quarterly. 
Customization or

Conformity? An

Institutional and

Network Perspective on

the Content and

Consequences of

TQM Adoption

James D. Westphal

University of Texas at Austin

Ranjay Gulati

Stephen M. Shortell

Northwestern University

(C) 1997 by Cornell University. 0001-8392/97/4202-0366/\$1.00.

The authors thank Rakesh Khurana, Mark Shanley, and Edward Zajac for valuable comments on earlier versions of this paper. The paper has also benefited from the helpful comments of Christine Oliver and three anonymous reviewers for $A S O$, as well as the editorial assistance of Linda Johanson. The following groups provided data used in this study: The AHA Hospital Research and Educational Trust, the AHA Data Survey Group, the Joint Commission on Accreditation of Health Care Organizations, and the Health Care Investment Analysts. We also thank the Baxter Foundation and the Graduate Program in Health Services Management at the Kellogg Graduate School of Management for generously funding this research. Additional support was provided by the A.C. Buehler Chair in Health Services Management at the Kellogg School. An earlier version of the paper received the 1996 West Press Best Paper Award in the Organization and Management Theory Division of the Academy of Management.
This study develops a theoretical framework that integrates institutional and network perspectives on the form and consequences of administrative innovations. Hypotheses are tested with survey and archival data on the implementation of total quality management (TQM) programs and the consequences for organizational efficiency and legitimacy in a sample of over 2,700 U.S. hospitals. The results show that early adopters customize TQM practices for efficiency gains, while later adopters gain legitimacy from adopting the normative form of TQM programs. The findings suggest that institutional factors moderate the role of network membership in affecting the form of administrative innovations adopted and provide strong evidence for the importance of institutional factors in determining how innovations are defined and implemented. We discuss implications for theory and research on institutional processes and network effects and for the literatures on innovation adoption and total quality management.

Researchers in a variety of disciplines have long been interested in identifying conditions that facilitate the spread of technological and administrative innovations. Early studies in this area sought to identify economic and organizational factors that encouraged or hindered innovation adoption by individuals or organizations. Researchers examined the relationship between adoption and such variables as firm size, performance, functional differentiation, slack, and leader characteristics (e.g., Rosner, 1968; Moch and Morse, 1977; Kimberly and Evanisko, 1981). More recent empirical research has explored the role of macro-social factors in facilitating the spread of innovations, some from an institutional perspective (e.g., Baron, Dobbin, and Jennings, 1986; Mezias, 1990; Burns and Wholey, 1993). Institutional perspectives generally emphasize the role of social factors rather than economic or efficiency factors in driving organizational action, including external conformity pressures from regulatory bodies or parent organizations, social pressures from other organizations with ties to the focal organization, as well as collective, social construction processes (e.g., Meyer and Rowan, 1977; Burns and Wholey, 1993; Scott, 1995). In institutional environments these normative pressures contribute to isomorphism, or the emergence of common organizational practices over time (DiMaggio and Powell, 1983). Several recent studies have demonstrated how

interorganizational and macro-social factors such as regulatory pressure, as well as more traditional intraorganizational factors like performance, influence the likelihood of adopting organizational innovations (e.g., Baron, Dobbin, and Jennings, 1986; Davis, 1991; Palmer, Jennings, and Zhou, 1993).

While researchers have made significant advances in identifying behavioral determinants of innovation adoption at both the organizational and macro-social levels, several important issues remain largely unexplored. First, researchers have typically treated innovation as a discrete phenomenon, neglecting to examine variation in the form of adoption itself or in implementation. While some innovations are inherently discrete (e.g., specific accounting practices or executive incentive plans), most can vary appreciably in form. When the 


\section{TOM Adoption}

particular definition or content of an innovation is open to interpretation, as in the case of such innovations as reengineering, matrix management, zero-based budgeting, or total quality management (TOM), variation in the form of adoption may be especially high, such that classifying adoption as an either-or proposition becomes somewhat arbitrary. In such cases, it may be more appropriate to explore how organizations define and implement an innovation, rather than simply to predict whether organizations adopt at all. The importance of this issue is indicated by anecdotal evidence that the success of administrative innovations depends on how they are conceived and implemented (e.g., Lawler and Mohrman, 1985).

A second, unresolved issue concerns the role of interorganizational network ties in diffusion. In attempting to explain evidence that network connectedness can facilitate the spread of discrete innovations, organizational scholars have invoked theories ranging from vicarious learning driven by efficiency imperatives (Rogers, 1983; Mansfield, 1971) to mimetic isomorphism resulting from social cohesion and conformity pressure (Coleman, Katz, and Menzel, 1966; Fligstein, 1985; Burt, 1987; Palmer, Jennings, and Zhou, 1993). There has been little attempt in the diffusion literature to determine when each of these divergent theoretical perspectives is most applicable in explaining the spread of information about an innovation across organizations. Network effects have typically been viewed as fixed and invariant; theorists have not considered how the content of information flowing through networks may change with time.

A third, general shortcoming in the literature is that empirical tests of institutional processes have neglected to examine directly both economic and social consequences of adoption (Scott, 1995). Instead, studies have typically inferred the occurrence of institutionalization from changes in the rate of adoption (e.g., Carroll and Hannan, 1989; Edelman, 1992) or from the decreased predictive power of certain organizational factors over time (e.g., Tolbert and Zucker, 1983). As Scott (1995) noted, however, such residual effects do not necessarily capture institutional factors. For instance, the efficiency or internal effectiveness concerns that drive early adoption may be replaced by a different, unmeasured set of determinants for later adopters. Moreover, increases in the rate of adoption or mimetic isomorphism may reflect social learning efficiencies rather than institutionalization (Rogers, 1983; Abrahamson and Rosenkopf, 1993). In the absence of direct measures of economic and social consequences of adopting innovations, multiple interpretations of observed trends and residual effects are possible.

The present study addresses these issues by examining institutional and network effects on innovation adoption in the context of total quality management (TOM) programs introduced by general medical surgical hospitals over the period 1985 to 1993, a period of widespread diffusion of TOM among hospitals. TQM is defined here as a managerial innovation that emphasizes an organization's total commitment to the customer and to continuous improvement of every process through the use of data-driven, problem-solving approaches based on empowerment of employee groups and

367/ASQ, June 1997 
teams (Dean and Bowen, 1994). While TQM embodies a consistent management philosophy, the specific content or form of TQM adoption is open to interpretation, raising the potential for institutional effects in the development and implementation of TQM programs. We consider the potential for institutionalization in the form of TQM adoption, and we examine further how interorganizational network ties could moderate this process. We develop a contingency network perspective in which social network ties either facilitate customization of TOM in response to internal efficiency needs or promote conformity in response to external legitimacy pressures, depending on the stage of institutionalization and the attendant motivation for adoption. Moreover, our approach develops a stronger test of institutional effects on organizational outcomes by addressing the consequences of conformity for both social legitimacy and economic efficiency.

This paper also contributes to the growing empirical literature on TQM. In one of the few large-sample, academic studies investigating the performance consequences of TQM, Powell (1995a) concluded that most organizational features commonly associated with TQM do not yield significant performance benefits. We offer a theoretical explanation for such findings: when TQM adoption is driven by conformity pressures rather than technical exigencies, firms may realize legitimacy benefits rather than technical performance benefits from adoption. To test this explanation, we simultaneously investigate both the performance consequences of innovation and the legitimacy benefits of conformity by considering whether a transition occurred from one kind of benefit to another as the form of TQM became institutionalized.

\section{TQM As an Administrative Innovation in the Hospital Environment}

An innovation is defined as "any idea, practice or material artifact perceived to be new by the relevant unit of adoption" (Zaltman, Duncan, and Holbek, 1973: 158). The tendency for researchers to conceive of innovation as a discrete phenomenon may derive from an emphasis in this literature on technological rather than administrative innovations (Damanpour, 1987). Whereas the presence or absence of technological innovations is relatively unambiguous, the definition of administrative innovations is often open to multiple interpretations. Moreover, such innovations can potentially include many different routines that can be combined in different ways. Accordingly, in the case of administrative innovations, it is frequently difficult to determine conformity from adoption alone; it may be necessary to examine conformity in the form of the innovation adopted or how it is implemented, treating the adoption of such innovations as continuous rather than discrete occurrences. This is particularly true for TQM, which is a relatively complex, pervasive innovation designed to affect all parts of an organization.

The TOM philosophy has four basic aspects (Anderson, Rungtusanatham, and Schroeder, 1994; Waldman, 1994). First, it has a customer focus. TOM emphasizes the improvement of processes for both internal and external cus- 
tomers. Internal customers include one's fellow workers, while external customers include not only those who purchase the good or service but also one's suppliers and other groups operating in the larger environment that influences the firm's success (e.g., regulatory bodies). Great attention is paid to identifying customer needs and expectations and then developing products and services that meet or exceed these expectations. Second, TQM emphasizes continuous improvement: it advocates a culture in which people are not satisfied with meeting current standards but, rather, push to exceed those standards. The emphasis is on raising standards by comparing one's efforts with the best in the industry or in the world. Organizations adopting TOM reject the dictum, "If it ain't broke, don't fix it." The new dictum becomes, "If it ain't broke-break it!" if by doing so the process or product can be improved. At the heart of continuous improvement is the notion of the learning organization (Senge, 1990). Continuous improvement is achieved through constant experimentation, learning from mistakes and diffusing the learning throughout the organization.

Third, TQM involves structured, problem-solving processes for identifying and solving problems and finding opportunities for improvement (Deming, 1993). These processes may include such techniques and tools as cause-and-effect diagrams, histograms, runs charts, pareto diagrams, statistical process control charts, and affinity diagrams (Hackman and Wageman, 1995). The common goal of these various practices is to reduce systematic or common variance from quality standards. Once the process is brought under control, attention then focuses on reexamining the process to see if it can be further improved through developing even tighter standards.

Finally, TOM emphasizes employee empowerment. A major tenet of the TOM philosophy is that continuous improvement is most likely to occur with groups of individuals who are provided with not only knowledge, skills, and motivation but also with the authority to take action (Crosby, 1984). Most of the knowledge to improve a given product or service is thought to rest with those directly involved in producing the good or service, and their knowledge must be tapped (Juran, 1989). This objective may be partially met through multifunctional, multidivisional teams trained in interpersonal skills and group processes. In general, while TOM can include many different policies and activities in different combinations, all TQM programs share the common objective of channeling the organization's energy toward the customer (Anderson, Rungtusanatham, and Schroeder, 1994).

Among extant administrative innovations, TOM seems a particularly good one for studying social conformity in the form of innovation adoption. While little empirical evidence is available on the overall performance consequences of TOM, even less is known about the ideal form or content of TOM programs. As a result, decision makers face considerable uncertainty about which form of TQM adoption is most technically efficient. For hospitals, added to this uncertainty are external accountability pressures (e.g., from the Joint Commission on Accreditation) to provide visible evidence of commitment to improved quality (Griffith, Sahney, and Mohr, 
1995). Given that "uncertainty is a powerful force that encourages imitation" (DiMaggio and Powell, 1983: 151) and that normative pressure from accrediting agencies provides an additional incentive to conform (Scott, 1987), TQM adoption among hospitals represents an appropriate setting to study the operation of institutional processes. Further, recent evidence suggests that it is the implementation processes associated with TOM adoption that are most important for improving quality and performance outcomes in hospitals (Shortell, O'Brien, and Carman, 1995; Beyer, Ashmos, and Osborn, 1997).

\section{THEORY AND HYPOTHESES}

\section{Customization and Conformity in TQM Adoption}

Organizational scholars suggest that institutionalization is a social process by which structures, policies, and programs acquire "rule-like status" as legitimate elements of the organization (Meyer and Rowan, 1977: 341; Zucker, 1977, 1983). Most empirical studies trying to demonstrate institutionalization have inferred this process from the declining predictive power of certain organizational factors over time. For instance, Tolbert and Zucker (1983) proposed that early adoptions of civil service reforms were motivated by technical or economic needs, while later adopters responded to the growing social legitimacy of these programs as taken-forgranted improvements in organizational structure. Consistent with this hypothesis, city characteristics predicted the likelihood of adoption among early adopters but not among later adopters. Similar findings have been obtained in studies investigating the adoption of personnel programs (Baron, Dobbin, and Jennings, 1986), the spread of city finance agencies (Meyer, Stevenson, and Webster, 1985), and the adoption of CEO incentive plans (Westphal and Zajac, 1994). As these and other administrative innovations become institutionalized, their adoption becomes "in some measure beyond the discretion of any individual ... organization" (Meyer and Rowan, 1977: 344).

Like many administrative innovations, TOM represents an integrated management philosophy (Powell, 1995a) rather than a clearly defined technology or set of techniques. From an institutional perspective it is quite feasible that TOM could invoke the socially legitimate goal of improving quality without dictating a well-defined routine for accomplishing it. For such administrative innovations, the appropriate question may not only be whether organizations adopt but how they adopt. Specifically, do hospitals develop TQM initiatives that conform to normative forms of TQM adoption, or do they customize TQM to the hospital's unique needs and capabilities? Conformity to normative adoption can involve, for instance, the selection of quality practices most commonly used by other adopters, or it can involve the adoption of standard and accepted approaches to TQM (e.g., Deming's, Crosby's, or Juran's).

Adoption of an innovation could take several different forms. If organizations can minimize evaluation and inspection of

370/ASQ, June 1997 
their internal operations by external constituents through adoption alone, they may neglect implementation altogether, decoupling operational routines from formally adopted programs (Meyer and Rowan, 1977; Oliver, 1991; Pfeffer, 1981; Zajac and Westphal, 1995). In the adoption of ambiguous administrative innovations that involve actual inspection by an external agency at the level of operational routines, complete decoupling may not occur, and organizations may instead accommodate institutional demands by conforming to socially legitimate operational definitions of institutional goals. Oliver (1991: 152) described this response to institutional pressures as "acquiescence," in contrast to "avoidance." This scenario applies to many organizations in institutional environments in which external legitimating agencies may wield tight and intrusive controls (Scott and Meyer, 1983; Scott, 1987). Among hospitals, external control over the adoption of TQM is exercised by the Joint Commission on Accreditation of Health Care Organizations (JCAHO), which regularly reviews the quality of care provided by hospitals by examining medical records, looking for documented evidence of certain quality improvement practices, and observing whether hospitals use structures and policies such as quality improvement project teams and procedures for gathering and reviewing quality data. In addition to such coercive isomorphic pressures, there may be mimetic tendencies, resulting from uncertainty about which specific routines TQM actually comprises (DiMaggio and Powell, 1983). Together, mimetic and coercive institutional processes can contribute to an emergent norm regarding the operational definition of TQM or how it is implemented in the organization.

Institutional theory suggests that this norm emergence process is built, ironically, on the efficiency motives of early adopters (Tolbert and Zucker, 1983; Zucker, 1983; Scott, 1987). Hospitals perceiving manifest opportunities to improve performance with TQM programs should be the first to adopt. As the initial TOM adopters, seeking technical efficiency gains, customize their quality practices to the unique problems and opportunities facing their organizations, they fuel institutional isomorphic processes by prompting legitimacy concerns among remaining nonadopters. Given that early adopters perceive more obvious opportunities for efficiency gains from TQM, their models of TQM adoption should be relatively successful, increasing normative pressure on remaining hospitals to develop isomorphic programs (DiMaggio and Powell, 1983). Conversely, given that later adopters are less likely to have perceived an obvious way to adapt TQM to the organization's capabilities, they are more likely to imitate the models advanced by early adopters. Thus, institutional isomorphism is manifested empirically as increased conformity over time to normative TQM adoption. Accordingly, institutional forces affect not merely the decision about whether to adopt TOM, as suggested by prior studies (e.g., Tolbert and Zucker, 1983), but also the determination of what TQM is, or what it should comprise. This suggests the following, initial hypothesis:

Hypothesis $1(\mathrm{H} 1)$ : The later the date of TQM adoption, the greater the level of conformity to the normative pattern of quality practices introduced by other adopting organizations. 


\section{Network Connectedness and Conformity in TQM Adoption}

Several researchers have examined how interorganizational and interpersonal relations affect the likelihood of adopting discrete innovations. Rogers (1983) argued that exposure to interpersonal channels of communication should promote early awareness of innovations, increasing the rate of adoption. This proposition is supported by a considerable body of research on innovation adoption and related studies examining the effect of network ties on the decision making of individuals or organizations. Social network ties to adopters have been shown to increase the likelihood of adopting medical technology and techniques (Coleman, Katz, and Menzel, 1966; Becker, 1970), matrix management programs (Burns and Wholey, 1993), the multidivisional form (Palmer, Jennings, and Zhou, 1993), and poison pills (Davis, 1991). ${ }^{1}$ Additional evidence suggests that firms are more likely to donate to specific charities or political action committees, engage in corporate acquisitions, or make other changes in corporate strategy or governance structure if decision makers have ties to leaders of other firms engaging in similar practices (Galaskiewicz and Wasserman, 1989; Mizruchi, 1992; Haunschild, 1993; Gulati, 1995b; Westphal and Zajac, 1997). Finally, a more diffuse literature on technology transfer provides considerable evidence that interorganizational relationships or common governance structures facilitate the spread of particular innovations across organizations (e.g., Tushman, 1977; Darr, Argote, and Epple, 1995) or promote innovation in general (e.g., Shan, Walker, and Kogut, 1994).

Interpretations of such findings vary widely (Abrahamson, 1991). According to Levitt and March (1988: 330), communication ties facilitate "a match between technology and organization" by helping decision makers learn about innovations that fit unique organizational needs and opportunities (see also Mansfield, 1971; Rogers, 1983). By contrast, other theorists have suggested that communication ties encourage mimetic isomorphism by informing decision makers about legitimate practices and possibly by exerting normative pressure toward conformity (e.g., Galaskiewicz and Wasserman, 1989; Haunschild, 1993; Palmer, Jennings, and Zhou, 1993). While both perspectives conceive communication ties as a vehicle for social learning (Bandura, 1977), such learning promotes organizational efficiency in the former perspective and social legitimacy in the latter.

Zucker's (1983) institutionalization thesis helps reconcile these potentially divergent interpretations of the relationship between social network ties and innovation adoption. Her primary claim is that the motivation for adopting organizational structure shifts from internal, efficiency concerns to external, legitimacy concerns over time as the structure becomes institutionalized. Applying this hypothesis to a network context, we expect that in later stages of the diffusion process, when innovations have acquired institutional status, communication ties could help disseminate information about legitimate forms of innovation adoption, while also possibly increasing normative pressure to conform to those practices. In earlier stages of the diffusion process, by contrast, communication ties may help match innovations to or- 
ganizations' unique efficiency needs. Thus, the content of information disseminated through network ties, and the resulting influence of networks on firm behavior, is contingent on the stage of institutionalization. This idea departs from prior network research in recognizing that network effects may not be constant over time.

In the context of TOM adoption, social networks may influence the form of practices adopting organizations introduce by informing decision makers about the normative form of TQM as it emerges over time. For initial TQM adopters, who are seeking efficiency gains from and face relatively minor institutional pressures, social ties to other adopters may facilitate efforts to match or customize quality practices to the efficiency needs and opportunities facing their organizations. Social network ties may furnish an opportunity for early adopters to learn vicariously from the experience of other hospitals using TQM practices (Mansfield, 1971; Levitt and March, 1988; Huber, 1991). Such ties facilitate knowledge transfer about which quality practices satisfy specific organizational objectives and, perhaps more importantly, which practices exploit the focal organization's distinctive capabilities and resources. For early TQM adopters, therefore, network ties would promote customization rather than isomorphism. As TOM becomes taken for granted or socially expected as an organizational policy, network ties can help organizations learn about the particular combination of practices commonly recognized and accepted as TOM. In later stages of the diffusion process, therefore, network ties to other adopters should encourage conformity in the form of TQM adoption.

Two kinds of network ties may be especially conducive to the transfer of knowledge about quality practices between hospitals: common membership in strategic alliances and multihospital systems. Alliances involve contractual arrangements between hospitals for the provision of goods and services, while systems bind hospitals together under common ownership. Hospital alliances and systems are frequently characterized by high levels of informal and formal communication between member organizations (McKinney, Kaluzny, and Zuckerman, 1991; Gustafson and Hundt, 1995). The close, multiplex network ties afforded by alliance and system memberships facilitate the flow of information between hospitals connected to each other, which promotes mutual understanding of each organization's distinctive capabilities and needs and increases the quality and relevance of advice from clinicians and executives of partner hospitals who have experience in developing TOM programs. The development of a common language between alliance or system members can further enhance the quality of communication (Zenger and Lawrence, 1989; Williams and Gibson, 1990), and trust and common interests afforded by social ties can enhance the willingness to provide it (Levitt and March, 1988; Gulati, 1995a, 1995b). For early adopters, therefore, communications between alliance and system members should facilitate customization of TOM adoption to the hospital's distinctive capabilities and weaknesses; for later adopters, such communications should facilitate conformity to in- 
stitutional pressures by raising awareness of normative TQM practices. This discussion suggests the following hypotheses:

Hypothesis $2(\mathrm{H} 2)$ : The time of TOM adoption will interact with adoption by alliance partners to predict conformity in TQM adoption by the focal hospital.

Hypothesis 2a ( $\mathrm{H} 2 \mathrm{a})$ : Among late adopters, the greater the number of alliance partners having adopted TOM, the higher the level of conformity to the normative pattern of TQM adoption.

Hypothesis $2 b(\mathrm{H} 2 \mathrm{~b})$ : Among early adopters, the greater the number of alliance partners having adopted TOM, the lower the level of conformity to the normative pattern of TQM adoption.

Hypothesis $3(\mathrm{H} 3)$ : The time of TOM adoption will interact with adoption by other system members to predict conformity in TQM adoption by the focal hospital.

Hypothesis $3 a(\mathrm{H} 3 \mathrm{a})$ : Among late adopters, the greater the number of other system members having adopted TOM, the higher the level of conformity to the normative pattern of TQM adoption.

Hypothesis $3 b(\mathrm{H} 3 \mathrm{~b})$ : Among early adopters, the greater the number of other system members having adopted TQM, the lower the level of conformity to the normative pattern of TOM adoption.

\section{The Consequences of Customization or Conformity in TQM Adoption}

As innovations become institutionalized as legitimate and expected elements of the organization, benefits from adoption may become increasingly social rather than economic or technical. According to DiMaggio and Powell (1983: 141), "as an innovation spreads, a threshold is reached beyond which adoption provides legitimacy rather than improves technical performance" (see also Abrahamson, 1991: 588). As TQM acquires institutional status, quality practices will be evaluated by a "logic of social appropriateness" rather than a "logic of instrumentality" (Campbell, 1994: 7). Accordingly, later TQM adopters should experience both the benefits and costs of social conformity. While opportunities to customize quality practices are diminished, by conforming to normative TQM adoption an organization's quality program "[will] be taken for granted as legitimate, apart from evaluations of [its] impact on work outcomes" (Meyer and Rowan, 1977: 344). In contrast, the earliest adopters, motivated by the opportunity for efficiency gains and free from the "iron cage" of isomorphic pressures (DiMaggio and Powell, 1983: 147; Zucker, 1983), should realize relatively higher performance gains by implementing quality practices that capitalize on their distinctive competencies and compensate for relative weaknesses. Prior empirical research has not directly examined this transition from technical to social legitimacy benefits from innovation adoption.

The importance of examining legitimacy versus technical benefits is particularly salient in studying TQM adoption because, by focusing exclusively on the technical performance effects of adopting quality practices, prior studies in the TQM literature may have underspecified the social consequences of adoption. While evidence for performance benefits from TQM is mixed (Powell, 1995a), minimal or negative performance effects do not necessarily imply that TOM fails to generate competitive advantage. Instead, organizations experiencing negligible efficiency gains from TOM may 
have effectively traded internal efficiency benefits for external legitimacy benefits by conforming to normative quality practices. This discussion leads to hypotheses on the consequences of conformity for legitimacy and performance:

Hypothesis $4(\mathrm{H} 4)$ : Conformity by a hospital to the normative pattern of quality practices implemented by other TOM adopters will be positively associated with organizational legitimacy.

Hypothesis 5 (H5): Conformity by a hospital to the normative pattern of quality practices implemented by other TOM adopters will be negatively associated with organizational efficiency.

Overall, the hypotheses suggest that conformity to normative TQM adoption should effectively mediate the relationship between time of adoption and the organizational consequences of adoption, such that the time of adoption should predict the degree of conformity, and conformity, in turn, should predict whether hospitals derive primarily efficiency or legitimacy benefits from adoption.

\section{METHOD}

\section{Background on the Population}

The study population was all community general medical surgical hospitals in the period 1985-1993, a sample frame of 5,492 organizations, 84 percent of which are not-for-profit. Widespread diffusion of TOM among these organizations began in 1989, but major changes had occurred in the health care environment prior to 1989 . Perhaps the most prominent change occurred in 1983, when diagnostic related groups (DRGs) were introduced as a way to determine reimbursement rates for Medicare patients; this system imposed significant new efficiency pressures on hospitals. In the last few years (i.e., largely after the period of adoption examined here), hospitals have experienced more intense pressure from managed care providers to contain costs.

Hospitals are embedded in larger networks through their memberships in alliances and systems. On average, a hospital is involved in one alliance, and an alliance includes approximately twenty hospitals. In general, alliances are regionally based, extending across state boundaries. Alliance partners can engage in multiple activities, including in-house seminars, joint training of staff, cross-system improvement projects, institutes for clinical effectiveness, analyses of outcomes of care, and sharing of best practices, and these activities often involve multiple alliance members (McKinney, Kaluzny, and Zuckerman, 1991; Gustafson and Hundt, 1995; Kaluzny, Zuckerman, and Ricketts, 1995). The multiplex and multilateral ties among alliance members provide a rich vehicle for the exchange of information about quality practices (Greer, 1977). In-house seminars and joint training sessions provide opportunities for administrators, physicians, and nurses from different hospitals to discuss and exchange information about the specific quality improvement tools and approaches (e.g., nominal group methods, brainstorming, control charts, etc.) used in their hospitals' TQM programs. These events give administrators and clinicians from different hospitals in an alliance the opportunity to form professional relationships with each other, providing the basis for future information exchange. 
There are approximately 300 hospital systems in the U.S., with an average of approximately nine hospitals per system. Research suggests that system ties typically facilitate the diffusion of innovations by reducing uncertainty and the risks associated with adoption, "helping [administrators] obtain important data on costs, problems, political risks, and innovation efficacy," "allowing potential adopters to learn from the experience of others," and creating group norms that favor adoption (McKinney, Kaluzny, and Zuckerman, 1991: 17-18). While innovations may be spread among members by virtue of a common, systemwide mandate, rather than through voluntary information sharing and imitation, this more coercive mechanism is atypical (McKinney, Kaluzny, and Zuckerman, 1991). For instance, the two largest systems in the dataset, the Hospital Corporation of America (HCA) and the American Medical International (AMI), made TOM voluntary for their member hospitals.

\section{Sample and Data Collection Instruments}

The data came from four sources: (1) the National Quality Survey, a focused survey of hospital quality improvement efforts; (2) the Joint Commission on Accreditation of Healthcare Organizations (JCAHO) national accreditation data; (3) financial performance data collected on a subsample of 300 hospitals, provided by Health Care Investment Analysts $(\mathrm{HClA})$, which collects archival data on hospitals' financial and economic performance; and (4) data on hospital size and alliance and system membership obtained from the Annual Survey of Hospitals, conducted by the American Hospital Association.

The National Quality Survey was sent by the hospital survey data center of the American Hospital Association in 1993 to the entire population of community general medical surgical hospitals $(N=5,492)$. The survey was completed by CEOs and top quality managers associated with 3,303 hospitals, representing a 60-percent return. Pretesting in 30 hospitals and discussion with industry experts had determined that the hospital's CEO and the hospital's top quality manager were the most knowledgeable and informed respondents to the questions. The survey asked for data on each hospital's quality improvement efforts, for example, time of adoption (overall and across specific practices), existence of quality improvement projects' teams, and use of quality improvement tools. The CEO was asked general questions on the hospital's overall quality improvement involvement, such as the existence of a quality improvement steering council, and the quality manager was asked more specific questions about TOM involvement, such as the use of particular quality improvement tools. Respondents were asked to indicate the impact of the quality improvement efforts on organizational efficiency.

We merged the survey data with each hospital's most recent (to 1993) accreditation data from the JCAHO, which is a national voluntary accreditation agency established in 1951 by the American College of Surgeons, the American College of Physicians, the American Dental Association, the American Hospital Association, and the American Medical Association to assess and improve the quality of care in U.S. hospitals. The JCAHO reviews the quality of care provided in U.S.

376/ASQ, June 1997 
hospitals and other health care organizations based on the extent to which they meet established standards in 49 areas, including medical staff, quality assessment and improvement, medical record-keeping, nursing care, laboratory services, and hospital governance and management functions.

Merging the two data sets yielded complete data for 2,712 hospitals. There were no differences between this sample and the larger population across any of the independent or dependent measures obtained from the separate archival sources (including the AHA data), except that hospitals in our sample were slightly more likely to be members of hospital systems (39 percent vs. 35 percent). The rate of TQM adoption among hospitals in our sample is close to the adoption rate for the population (73 percent vs. 70 percent). The 3-percent difference does not affect the findings discussed below, however, because our analysis is limited to those hospitals that have adopted TQM, while controlling for any possible sample selection bias using the Heckman selection model.

Finally, we obtained historical archival data on hospital performance, liquidity, slack resources, and cost control from Health Care Investment Analysts ( $\mathrm{HClA})$ for a random subsample of 300 hospitals. Complete data were available for 269 of the 300 hospitals. Separate analyses and summary data from $\mathrm{HClA}$ confirmed that this subsample is representative of the population across the independent and dependent measures.

\section{Dependent Measures}

Conformity. To measure conformity to the normative, or typical, pattern of TQM adoption, the survey first asked respondents to indicate whether their hospital had engaged in twenty different quality practices, which cover the range of interventions that have been implemented in TQM programs in hospitals (Berwick, Godfrey, and Roessner, 1990; Barsness et al., 1993). These practices include (1) various kinds of team structures (e.g., quality improvement councils), (2) statistical tools and process heuristics (e.g., control charts, pareto diagrams, cause-and-effect diagrams), (3) training, (4) quality reports, and (5) benchmarking (see Appendix for complete list). All are discussed in the literature as possible kinds of TQM interventions (e.g., Waldman, 1994; Hackman and Wageman, 1995; Powell, 1995a). We measured conformity by coding whether a hospital used a particular practice, then calculating the percentage of other hospitals adopting TQM in the same or earlier time period whose response (i.e., use/do not use) matched the focal hospital's response. We then summed these percentages across the twenty practices, yielding an overall measure of conformity (conformity measure 1).

For a subset of 45 hospitals we were able to examine the test-retest reliability of assessments about the use of individual quality practices from responses to an earlier survey. This subsample was representative of the larger sample in terms of hospital size, efficiency, legitimacy, and the use or nonuse of individual quality practices. We measured consistency in the responses by calculating kappa coefficients for 
each practice, a procedure that corrects for the amount of consistency over time expected by chance. Coefficients were significant for all twenty practices; the lowest level of consistency was 95.6 percent, and the average consistency was 97.8 percent. These high levels of reliability are not surprising, in that the questions elicit relatively objective, factbased information, rather than subjective information about attitudes.

A separate measure of conformity asked respondents whether their hospital followed a particular, standard TQM approach-those of Crosby, Deming, or Juran, widely recognized leaders of the total quality movement who created distinct approaches to TOM. Deming's approach emphasizes statistical tools and process heuristics, Crosby's focuses on training, and Juran's emphasizes quality audits (Crosby, 1984; Juran, 1989; Deming, 1993; Waldman, 1994; Hackman and Wageman, 1995). Respondents were asked whether they followed (1) one of these approaches, (2) a combination of one or more of these approaches, (3) some other, nonstandard approach, or (4) no particular approach. TQM programs that fall in the latter three categories can be viewed as more customized than programs that conform to a single, standard approach. The three standard approaches to TQM can be considered preexisting scripts available to guide implementation. By combining approaches, hospitals were customizing their TQM program, adding or subtracting features to suit their needs. This second measure of conformity was coded 1 if hospitals used a particular, standard TQM model (category 1 above), and 0 otherwise (conformity measure 2). The correlation between the two conformity measures was .54 , providing initial evidence for reliability. We nevertheless conducted two separate sets of analyses using each of these measures; the results are presented separately below.

Efficiency and legitimacy. We defined efficiency broadly, as institutional theorists have, and use the term synonymously with "organizational performance" and "the internal functioning of the organization" (Tolbert and Zucker, 1983: 26; see also Meyer and Rowan, 1977; Meyer, Scott, and Deal, 1983). We used multiple measures of efficiency. The first measure assessed the perceived impact of TQM on costs, the frequency of errors and inappropriate treatment, hospitalphysician relations, physician, nurse, and staff turnover, and patient satisfaction (perceived efficiency). This measure gauges the perceived effect of TQM on processes that affect efficiency. The reliability of this scale was satisfactory (alpha $=.88$ ), and factor analysis with principal factors estimation and varimax rotation confirmed that all items loaded on a single factor (estimated using the Bartlett method).

We also used two archival measures of hospital performance: return on equity (ROE) and the number of full-time equivalent employees (FTEs) per 100 admissions, calculated for the year following TQM adoption. ROE gauges profitability, and the second measure assesses productivity. Return on equity is a meaningful measure of performance for all hospitals in the sample, including not-for-profits, since the distinction between for-profit and not-for-profit hospitals is largely a legal one having to do with the distribution of re-

378/ASQ, June 1997 
tained earnings. The archival measures were positively correlated with the survey measure (.53 and .48 for productivity and profitability, respectively) and with each other (.44), providing evidence for convergent validity. Nevertheless, the results are presented separately below for each measure.

We measured hospital legitimacy with the overall JCAHO rating, which ranges from 0 (no compliance) to 100 (perfect compliance) and is calculated as a composite of 83 individual scores, measured as $1=$ substantial compliance; $2=$ significant; 3 = partial; 4 = minimal; and $5=$ no compliance. (In separate models, we applied a logistic transformation of the legitimacy measure, and the results discussed below were substantively unchanged.) Based on this overall evaluation, JCAHO accredits organizations achieving acceptable levels of performance. Accreditation imparts significant institutional legitimacy because it is a condition of hospital participation in the Federal Medicare Program and many state Medicaid programs. Scott (1987: 502) specifically cites the JCAHO as a source of institutional pressure on hospitals, and several authors have noted the significant impact of the JCAHO's monitoring and evaluation process on total quality practices (Lathrop, 1993: 29; Ziegenfuss, 1993: 20). The JCAHO did not change its standards or procedure for accreditation during our period of study.

\section{Independent Measures}

Time of adoption. TQM was first adopted by health care organizations in the late 1980s, largely in response to pressure from employers, purchasers, and payers to provide more cost-effective health care (Berwick, Godfrey, and Roessner, 1989, 1990; Laffel and Blumenthal, 1989). As shown in Figure 1, widespread diffusion began in 1989, following a large-scale, national demonstration program sponsored by private health care foundations (Berwick, Godfrey, and Roessner, 1989). The time of TOM adoption (late adoption) was divided into three categories: within two years, between two and four years previous, and more than four years previous to data collection in 1993. This time variable effectively divides early and late adopters at approximately the midpoint of the observed adoption period, with an additional category for the relatively few hospitals that adopted prior to the period of widespread adoption. In separate analyses, we operationalized time of adoption as a dichotomous variable by excluding hospitals that adopted more than four years previously (i.e., omitting category three), and the results reported below were substantively unchanged. We also operationalized time of adoption as the year in which one or more specific TQM practices were introduced. Again, the results were substantively unchanged, suggesting that our findings do not depend on one particular measure of time of adoption.

Network ties. We measured ties to alliance partners who had adopted TOM (alliance ties to adopters) as a count variable equal to the number of alliance partners who adopted TQM prior to the focal firm. Ties to fellow system members who had adopted TOM (system ties to adopters) were measured in the same way. Both measures include ties to other hospitals adopting prior to the focal hospital, even for those 
Figure 1. The cumulative adoption of TQM among general medical surgical hospitals.

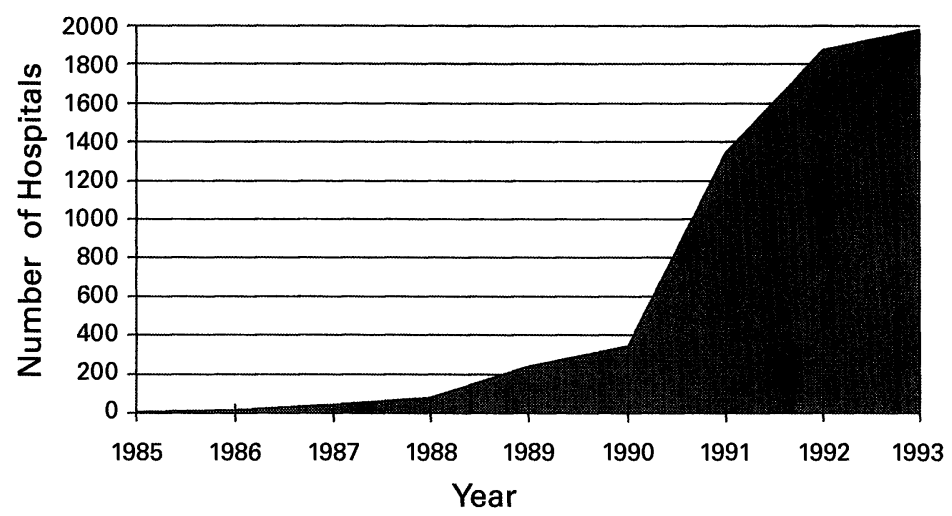

adopting in the same category of adoption period (e.g., for hospitals adopting in 1992 we included ties to hospitals adopting in 1991, even though both years are classified as late adoption).

We used the product term approach to assess the interactive effect of these network variables and late adoption on TQM conformity. First, to avoid any possible multicollinearity problem, all three variables were centered (Jaccard, Turrisi, and Wan, 1990). Although one study suggests that this transformation is unnecessary (Harrison and Mitchell, 1995), a clear consensus on this issue has not emerged. Because the centering procedure at best alleviates multicollinearity problems and at worst makes no difference, we elected to use it here. We created interaction terms as the product of each network variable and the time of adoption (alliance ties $\times$ late adoption and system ties $\times$ late adoption).

Control variables. We included several control variables in the analyses. We controlled for technological sophistication, measured by the number of high-technology services offered (trauma, stereostatic radiology, MRI, PET scanner, kidney transplant, organ transplant, thyroid transplant, bone marrow transplant), because such services are costly and therefore might provide hospitals with a greater impetus to adopt TQM for technical efficiency purposes. We used principal components to create an index of technical services offered (Jackson, 1991).

Given that market competition may provide an additional impetus toward isomorphism (Abrahamson and Rosenkopf, 1993), while also potentially affecting performance outcomes (Reed, Lemak, and Montgomery, 1996), we included a measure of competitive pressure (competition) in all models by combining four survey items measuring competition into a single factor using principal components factor analysis. The scree test and factor loadings confirmed that all four items loaded on a single factor. Specific items assessed the number of health maintenance organizations (HMOs) in the same market area, the percentage of all patients for which the hospital is paid on a per-capita basis, the number of hospitals that are direct competitors of the focal hospital, and the perceived intensity of competition. In addition, because isomorphic tendencies and legitimacy pressures may be associated 
with organizational size (DiMaggio and Powell, 1983: 152; Carroll and Hannan, 1989), we also included hospital size, measured as the total number of staffed beds.

We constructed additional control measures of hospital performance and certain organizational characteristics for the representative subsample of 269 hospitals. Since hospitals facing organizational inefficiencies or poor economic conditions are more likely to seek efficiency benefits from TOM, hospital productivity and profitability may be related to both the time of TOM adoption and the degree of conformity. Thus, we developed control variables for hospital profitability, measured as return on equity, and hospital productivity, measured as the number of full-time equivalent employees per 100 admissions (FTEs/100 admissions). We also controlled for organizational slack, measured as the hospital's administrative expenses as a percentage of total expenses (percent administrative expenses), because organizations with more abundant resources may be better able to experiment with new forms of TQM (cf. Cyert and March, 1963; Nohria and Gulati, 1995), making it easier to customize their TQM programs. Similarly, because hospitals enjoying high liquidity may also have a greater capacity for customization, we controlled for liquidity, using the prior debt service coverage ratio (Mizruchi and Stearns, 1988).

Finally, we used prior case mix expense per day as a measure of cost control, given that hospitals with inadequate cost control may tend to seek efficiency benefits from TOM adoption. This measure was calculated as the total number of outpatient visits, divided by inpatient admissions, and adjusted for the average severity of cases treated at the hospital. Higher values signify lower cost control. All five control variables were calculated for the year prior to the year of TQM adoption. Table 1 provides the means, standard deviations, and bivariate correlations for all hospitals in the sample. Note that we did not control for whether. hospitals were designated as not-for-profit rather than for-profit, because both groups have experienced strong external pressures to adopt quality practices; nevertheless, in separate analyses we included a control variable indicating not-forprofit vs. for-profit status, and the results presented below were substantively unchanged.

\section{Analysis}

To analyze each dependent variable of interest (i.e., conformity in TQM adoption and the consequences for organizational legitimacy and performance), we used the Heckman selection model, a two-staged procedure that corrects for sample selection bias in regression analysis (Heckman, 1979; Maddala, 1983). Given that conformity to normative quality practices is limited to firms that have adopted TQM, sample selection bias could threaten the generalizability of our results. For example, if hospitals that adopt TOM programs are more sensitive to institutional pressures or are better positioned to realize legitimacy benefits from conformity than non-adopters, then specification error would be present.

The Heckman selection model includes two equations: the first equation predicts whether or not an observation is observed, and the second equation predicts the outcome of

381/ASQ, June 1997 


\section{Descriptive Statistics and Pearson Correlation Coefficients*}

\begin{tabular}{|c|c|c|c|c|c|c|c|c|c|c|}
\hline Variable & Mean & S.D. & 1 & 2 & 3 & 4 & 5 & 6 & 7 & 8 \\
\hline 1. Conformity measure 1 & 7.182 & 2.473 & & & & & & & & \\
\hline 2. Conformity meas & .423 & .494 & .54 & & & & & & & \\
\hline 3. Late adoption & 1.306 & .541 & .23 & .20 & & & & & & \\
\hline 4. Alliance ties to adopters & 11.199 & 28.528 & .04 & .03 & .17 & & & & & \\
\hline 5. System ties to adopters & 6.104 & 15.146 & .01 & .02 & .16 & -.15 & & & & \\
\hline 6. Alliance ties $\times$ time of adop. & 1.101 & 18.400 & .22 & .20 & .20 & .19 & .01 & & & \\
\hline 7. System ties $\times$ time of adop. & .381 & 9.884 & .20 & .19 & .20 & .01 & .20 & -.09 & & \\
\hline 8. Number of beds & 230.041 & 200.483 & .11 & .12 & .13 & .22 & -.09 & .02 & -.01 & \\
\hline 9. Competition & .000 & .982 & .06 & .03 & -.06 & .05 & .01 & -.04 & .03 & .30 \\
\hline 10. Technological sophistication & .000 & 1.000 & -.04 & -.08 & -.26 & -.12 & .03 & -.01 & .01 & -.39 \\
\hline 11. Perceived efficiency & .000 & .863 & -.15 & -.17 & -.25 & .07 & .02 & -.17 & -.16 & .22 \\
\hline 12. Organizational legitimacy & 82.847 & 8.338 & .26 & .27 & .31 & -.06 & .02 & .13 & .11 & -.21 \\
\hline 13. Return on equity & 10.155 & 46.053 & -.18 & -.27 & -.29 & .05 & .02 & -.19 & -.16 & .18 \\
\hline 14. FTEs/100 admissionst & 5.832 & 1.499 & -.21 & -.25 & -.34 & .03 & -.01 & -.22 & -.27 & .25 \\
\hline 15. Prior return on equity & 10.428 & 50.823 & .15 & .16 & -.13 & -.06 & -.10 & .06 & .08 & -.02 \\
\hline 16. Prior $\%$ admin. expenses & 10.594 & 3.188 & -.09 & -.10 & -.14 & -.06 & .04 & .07 & -.05 & -.25 \\
\hline 17. Prior FTEs/100 admissions & 5.534 & 1.454 & -.16 & -.18 & .10 & -.04 & -.06 & .05 & .08 & .12 \\
\hline 18. Prior case mix expense/day & 516.273 & 164.262 & -.18 & -.18 & -.12 & -.08 & -.03 & .07 & .02 & -.09 \\
\hline 19. Prior debt service coverage ratio & 2.285 & 2.553 & .04 & .02 & -.06 & -.04 & -.04 & .01 & .02 & .05 \\
\hline Variable & 9 & 10 & 11 & 12 & 13 & 14 & 15 & 16 & 17 & 18 \\
\hline 10. 10 & -.20 & & & & & & & & & \\
\hline 11. Percei & .19 & -.20 & & & & & & & & \\
\hline 12. Organizational legitimacy & -.14 & .18 & -.01 & & & & & & & \\
\hline 13. Return on equity & .04 & .02 & .48 & -.13 & & & & & & \\
\hline 14. FTEs/100 admissio & .15 & .06 & .53 & -.16 & .44 & & & & & \\
\hline 15. Prior return on equity & -.08 & .07 & .37 & .04 & .41 & .2 & & & & \\
\hline 16. Prior $\%$ admin. expenses & -.07 & .18 & -.15 & -.13 & -.09 & -.12 & .16 & & & \\
\hline 17. Prior FTEs/100 admissions & -.06 & -.13 & -.10 & .04 & .22 & .39 & -.06 & .06 & & \\
\hline 18. Prior case mix expense/day & -.05 & .03 & .11 & .12 & -.07 & -.08 & -.04 & .39 & .2 & \\
\hline 19. Prior debt service coverage & .03 & -.03 & .06 & -.05 & .10 & .06 & .02 & .00 & .23 & .08 \\
\hline
\end{tabular}

* $N=1979$ for variables $1-11$ and 193 for variables $12-19$. All correlations involving variables $12-19$ reflect the smaller sample size.

tFor the bivariate correlations, values for this measure are subtracted from the highest value in the sample so that higher values reflect greater productivity; descriptives reflect actual values.

interest. In this case, the latter equation represents conformity in TQM practices while the former represents the likelihood of TQM adoption. When the error terms from these equations are significantly correlated, standard regression techniques applied to the second equation alone can yield biased results. In other words, to the extent that error terms in both equations contain some common omitted variables, selection bias will occur (van de Ven and van Praag, 1981). Heckman's procedure generates consistent, asymptotically efficient estimates for such models, allowing us to generalize to the larger population of hospitals (Heckman, 1979). The model first estimates the likelihood of TQM adoption with probit regression. The index function from the probit model is transformed into a hazard rate using the Mills ratio, and the estimated rate is then included in a second-stage regression model to predict conformity for those hospitals that have adopted. For the second measure of conformity, which is dichotomous rather than continuous, the second stage model is estimated with bivariate probit regression (van de Ven and van Praag, 1981).

We constructed two sets of Heckman models: the first set predicted conformity, legitimacy, and performance for the 


\section{TQM Adoption}

full sample of 2,712 hospitals, and the second set included the additional control variables for the representative subsample of 269 hospitals (193 adopters). In all of these models the first equation predicts TQM adoption. We also conducted separate analyses using Cochrane-Orcutt regression to ensure that estimates were not biased by serial correlation (Johnston, 1984); results for the hypothesized relationships were substantively unchanged from the results reported below.

\section{RESULTS}

Table 2 provides results for the Heckman selection models of conformity in TQM adoption, using the two different measures of conformity. Models 1 and 2 predict conformity to the normative pattern of adoption, as determined by the use or non-use of twenty different quality structures and practices (conformity measure 1), and models 3 and 4 predict conformity to a standard, legitimate TQM model (conformity measure 2). The second model of each pair includes additional control variables for the random subsample of 269 hospitals.

The results for models 1 and 3 support hypothesis 1 , that

Table 2

\begin{tabular}{|c|c|c|c|c|}
\hline \multicolumn{5}{|c|}{ Heckman Sample Selection Models of Conformity in TQM Adoption* } \\
\hline \multirow[b]{2}{*}{ Independent Variable } & \multicolumn{2}{|c|}{ Conformity Measure 1} & \multicolumn{2}{|c|}{ Conformity Measure 2} \\
\hline & Model 1 & Model 2 & Model 3 & Model 4 \\
\hline \multirow[t]{2}{*}{ Late adoption } & $.225^{\bullet \bullet}$ & $.802^{\bullet}$ & $.167^{\bullet \bullet}$ & $.534^{\bullet \bullet}$ \\
\hline & $(.093)$ & $(.317)$ & $(.064)$ & $(.206)$ \\
\hline \multirow[t]{2}{*}{ Alliance ties to adopters } & .001 & .002 & .001 & .002 \\
\hline & $(.001)$ & $(.004)$ & $(.001)$ & $(.002)$ \\
\hline \multirow[t]{2}{*}{ System ties to adopters } & .0001 & -.008 & -.001 & -.003 \\
\hline & $(.002)$ & $(.010)$ & $(.002)$ & $(.006)$ \\
\hline \multirow[t]{2}{*}{ Alliance ties $\times$ late adoption } & $.007^{\circ} \bullet$ & $.013^{\circ}$ & $.004^{\bullet}$ & $.009^{\circ}$ \\
\hline & $(.002)$ & $(.006)$ & $(.001)$ & $(.004)$ \\
\hline \multirow[t]{2}{*}{ System ties $\times$ late adoption } & $.010^{\circ}$ & $.051^{\circ}$ & $.006^{\circ}$ & $.037^{\circ} \cdot \bullet$ \\
\hline & $(.004)$ & $(.019)$ & $(.002)$ & $(.012)$ \\
\hline \multirow[t]{2}{*}{ Number of beds } & $.001^{\circ}$ & $.002^{\circ}$ & .0007 & $.002^{\circ}$ \\
\hline & $(.0005)$ & $(.001)$ & $(.0004)$ & $(.0007)$ \\
\hline \multirow[t]{2}{*}{ Competition } & .059 & .191 & .018 & .132 \\
\hline & $(.040)$ & $(.129)$ & $(.028)$ & (.087) \\
\hline \multirow[t]{2}{*}{ Technological sophistication } & -.005 & -.088 & -.009 & -.104 \\
\hline & $(.034)$ & $(.118)$ & $(.023)$ & $(.078)$ \\
\hline \multirow[t]{2}{*}{ Prior return on equity } & & $.015^{\circ}$ & & $.131^{\circ}$ \\
\hline & & $(.007)$ & & $(.053)$ \\
\hline \multirow[t]{2}{*}{ Prior percent administrative expenses } & & -.064 & & -.058 \\
\hline & & $(.057)$ & & $(.038)$ \\
\hline \multirow[t]{2}{*}{ Prior FTEs/100 admissions } & & $-.339^{\bullet}$ & & $-.209^{\circ}$ \\
\hline & & (.124) & & $(.085)$ \\
\hline \multirow[t]{2}{*}{ Prior case mix expense per day } & & $-.002^{\circ}$ & & $-.002^{\circ}$ \\
\hline & & $(.001)$ & & $(.001)$ \\
\hline Prior debt service coverage ratio & & $\begin{array}{c}.051 \\
(.086)\end{array}$ & & $\begin{array}{c}125 \\
(.114)\end{array}$ \\
\hline \multirow[t]{2}{*}{ Constant } & $2.710^{\bullet \bullet \bullet}$ & $7.534^{\circ} \bullet$ & .434 & 1.329 \\
\hline & $(.343)$ & $(1.483)$ & $(.241)$ & $(1.011)$ \\
\hline Chi-square & $69.94^{\bullet \cdots}$ & $40.82^{\bullet}$ & $52.86^{\bullet \cdots}$ & $37.40^{\circ \cdots}$ \\
\hline Pseudo $R$-square & .34 & .43 & .31 & .41 \\
\hline Rho $(\rho)$ & .51 & .54 & .49 & .50 \\
\hline$N$ & 2712 & 269 & $2712^{.70}$ & $269^{\circ}$ \\
\hline
\end{tabular}

$\bullet p \leq .05 ;{ }^{\bullet} p \leq .01 ; \cdots p \leq .001 ;$ t-tests are one-tailed for hypothesized effects, two-tailed for control variables. * Unstandardized coefficients are reported. Standard errors are in parentheses. 
later adopters would be more likely than early adopters to conform to the normative pattern of quality practices introduced by other adopting organizations. After controlling for the significant effect of hospital size on conformity, as well as the effect of competition and technological sophistication, time of TQM adoption is positively and significantly related to both measures of conformity in the form of TQM adoption. Moreover, using a separate survey question that asked respondents to indicate when a subset of specific quality practices were introduced, we constructed a separate measure of conformity and found that the results were substantively unchanged. Thus, the observed relationship between time of adoption and conformity cannot be attributed to early adopters customizing their TQM programs over time.

Hypothesis 2 predicted an interaction effect between the prevalence of adoption among other alliance partners and the time of adoption on the degree of conformity in TQM adoption. Specifically, we predicted that for late adopters, the greater the number of alliance partners having adopted TQM, the higher the level of conformity to the normative pattern of TQM adoption, while for early adopters, ties to prior adopters would be negatively related to conformity. The results shown in Table 2 provide strong support for this hypothesized interaction. The consistently significant coefficients for "alliance ties to adopters $\times$ late adoption" indicate that the positive relationship between time of adoption and

Table 3

\begin{tabular}{|c|c|c|c|c|}
\hline \multicolumn{5}{|c|}{ Heckman Sample Selection Models of Hospital Legitimacy* } \\
\hline \multirow[b]{2}{*}{ Independent Variable } & \multirow[b]{2}{*}{ Model 1} & \multicolumn{2}{|c|}{ Unstandarized Coefficients } & \multirow[b]{2}{*}{ Model 4} \\
\hline & & Model 2 & Model 3 & \\
\hline Conformity measure 1 & $\begin{array}{l}.064^{\cdots \bullet} \\
(.019)\end{array}$ & $\begin{array}{l}.209^{\circ} \bullet \\
(.065)\end{array}$ & & \\
\hline Conformity measure 2 & & & $\begin{array}{l}.383^{\bullet \bullet} \\
(.068)\end{array}$ & $\begin{array}{l}.648^{\circ \cdots \bullet} \\
(.263)\end{array}$ \\
\hline Late adoption & $\begin{array}{l}.067 \\
(.064)\end{array}$ & $\begin{array}{l}.176 \\
(.221)\end{array}$ & $\begin{array}{l}.057 \\
(.063)\end{array}$ & $\begin{array}{l}.172 \\
(.224)\end{array}$ \\
\hline Number of beds & $\begin{array}{l}.001^{\circ} \\
(.0004)\end{array}$ & $\begin{array}{l}.001 \\
(.0008)\end{array}$ & $\begin{array}{l}.001^{\bullet \bullet} \\
(.0004)\end{array}$ & $\begin{array}{l}.001 \\
(.0008)\end{array}$ \\
\hline Competition & $\begin{array}{c}-.033 \\
(.029)\end{array}$ & $\begin{array}{c}-.126 \\
(.092)\end{array}$ & $\begin{array}{c}-.033 \\
(.028)\end{array}$ & $\begin{array}{c}-.130 \\
(.094)\end{array}$ \\
\hline Technological sophistication & $\begin{array}{c}-.014 \\
(.024)\end{array}$ & $\begin{array}{c}-.135 \\
(.081)\end{array}$ & $\begin{array}{c}-.013 \\
(.023)\end{array}$ & $\begin{array}{c}-.138 \\
(.081)\end{array}$ \\
\hline Prior return on equity & & $\begin{array}{c}.001 \\
(.003)\end{array}$ & & $\begin{array}{l}.001 \\
(.003)\end{array}$ \\
\hline Prior percent administrative expenses & & $\begin{array}{r}-.084^{\circ} \\
(.038)\end{array}$ & & $\begin{array}{r}-.091^{\circ} \\
(.039)\end{array}$ \\
\hline Prior FTEs/100 admissions & & $\begin{array}{l}.089 \\
(.086)\end{array}$ & & $\begin{array}{l}.091 \\
(.083)\end{array}$ \\
\hline Prior case mix expense per day & & $\begin{array}{c}.0006 \\
(.0009)\end{array}$ & & $\begin{array}{c}.0005 \\
(.0009)\end{array}$ \\
\hline Prior debt service coverage ratio & & $\begin{array}{c}-.039 \\
(.052)\end{array}$ & & $\begin{array}{c}-.043 \\
(.051)\end{array}$ \\
\hline Constant & $\begin{array}{l}1.073^{\circ} \\
(.254)\end{array}$ & $\begin{array}{c}2.256^{\circ} \\
(1.056)\end{array}$ & $\begin{array}{c}1.041^{\cdots} \\
(.249)\end{array}$ & $\begin{array}{r}2.327^{\circ} \\
(1.032)\end{array}$ \\
\hline Chi-square & $59.38^{\cdots}$ & $33.82^{\cdots}$ & $61.25^{\circ}$ & $27.34^{\bullet \bullet}$ \\
\hline Pseudo R-square & .25 & .35 & .26 & .32 \\
\hline Rho $(\rho)$ & .55 & .57 & .55 & .57 \\
\hline$N$ & 2712 & 269 & 2712 & 269 \\
\hline
\end{tabular}

$\bullet p \leq .05 ; \cdots p \leq .01 ; \cdots p \leq .001 ; t$-tests are one-tailed for hypothesized effects, two-tailed for control variables.

* Standard errors are in parentheses. 


\section{TQM Adoption}

conformity increases significantly as alliance ties to other adopters increases. Moreover, analysis of simple effects confirmed that the coefficient for alliance ties is negatively related to conformity for early adopters (i.e., firms adopting two or more years previously) and positively related to conformity for late adopters (i.e., firms adopting within two years), across both measures of conformity.

A similar pattern of results in Table 2 supports hypothesis 3 : for both measures of conformity, system ties to other adopters significantly increased the positive relationship between time of adoption and the degree of conformity in TQM adoption. Together with the insignificant main effect for system ties (and unreported simple effects that mirror those for alliance ties), these results show that system ties to other adopters decrease conformity for early adopters and increase conformity for later adopters. Overall, network connectedness to other TQM adopters encourages conformity to normative quality practices among later adopters, while discouraging conformity (i.e., promoting customization) among early adopters. These findings do not appear to result from differences in the attributes of hospitals to which early and late adopters are connected. The networks of early adopters do not differ from those of late adopters in terms of the prevalence of teaching hospitals, average hospital size, geographic region, or average technological sophistica-

Table 4

\begin{tabular}{|c|c|c|c|c|}
\hline \multicolumn{5}{|c|}{ Heckman Sample Selection Models of Hospital Legitimacy* } \\
\hline \multirow[b]{2}{*}{ Independent Variable } & \multicolumn{4}{|c|}{ Perceived Efficiency } \\
\hline & Model 1 & Model 2 & Model 3 & Model 4 \\
\hline Conformity measure 1 & $\begin{array}{r}-.032^{\bullet} \\
(.015)\end{array}$ & $\begin{array}{l}-.153^{\bullet \cdots} \\
(.050)\end{array}$ & & \\
\hline Conformity measure 2 & & & $\begin{array}{l}-.143^{\bullet} \\
(.055)\end{array}$ & $\begin{array}{l}-.687^{\circ} \cdot \bullet \\
(.209)\end{array}$ \\
\hline Late adoption & $\begin{array}{l}-.386^{\bullet \cdots} \\
(.054)\end{array}$ & $\begin{array}{l}-.681^{\bullet \cdots} \\
(.209)\end{array}$ & $\begin{array}{l}-.386^{\circ} \\
(.054)\end{array}$ & $\begin{array}{l}-.700^{\circ} \\
(.203)\end{array}$ \\
\hline Number of beds & $\begin{array}{l}.002^{\circ} \cdot . \\
(.0003)\end{array}$ & $\begin{array}{l}.2001^{\circ} \\
(.0007)\end{array}$ & $\begin{array}{l}.002^{\circ} \cdots \\
(.0003)\end{array}$ & $\begin{array}{l}.2001^{\circ} \\
(.0007)\end{array}$ \\
\hline Competition & $\begin{array}{l}.082^{\circ} \cdot \\
(.024)\end{array}$ & $\begin{array}{l}.119 \\
.1 .084)\end{array}$ & $\begin{array}{l}.082^{\circ \cdots} \\
(.024)\end{array}$ & $\begin{array}{l}.129 \\
(.083)\end{array}$ \\
\hline Technological sophistication & $\begin{array}{l}.016 \\
(.023)\end{array}$ & $\begin{array}{l}.039 \\
(.084)\end{array}$ & $\begin{array}{l}.016 \\
(.023)\end{array}$ & $\begin{array}{l}.049 \\
(.084)\end{array}$ \\
\hline Prior return on equity & & $\begin{array}{l}.012^{\bullet} \\
(.003)\end{array}$ & & $\begin{array}{l}.012^{\circ} \\
(.003)\end{array}$ \\
\hline Prior percent administrative expenses & & $\begin{array}{l}.012 \\
(.036)\end{array}$ & & $\begin{array}{l}.019 \\
(.036)\end{array}$ \\
\hline Prior FTEs/100 admissions & & $\begin{array}{r}-.150^{\circ} \\
(.074)\end{array}$ & & $\begin{aligned}-.149^{\circ} \\
(.073)\end{aligned}$ \\
\hline Prior case mix expense per day & & $\begin{array}{l}.001 \\
(.0007)\end{array}$ & & $\begin{array}{l}.001 \\
(.0007)\end{array}$ \\
\hline Prior debt service coverage ratio & & $\begin{array}{l}.052 \\
(.069)\end{array}$ & & $\begin{array}{l}.044 \\
(.067)\end{array}$ \\
\hline Constant & $\begin{array}{l}.991^{\bullet \bullet \bullet} \\
(.229)\end{array}$ & $\begin{array}{c}.0053 \\
.353 \\
(.938)\end{array}$ & $\begin{array}{l}.979^{\bullet \bullet \bullet} \\
(.214)\end{array}$ & $\begin{array}{c}.320 \\
.320 \\
(.877)\end{array}$ \\
\hline Chi-square & $96.03^{\bullet \bullet}$ & $107.26^{\circ}$ & $99.08^{\bullet \bullet}$ & $104.13^{\bullet}$ \\
\hline Pseudo $R$-square & .40 & .52 & .42 & .52 \\
\hline Rho $(\rho)$ & .47 & .50 & .47 & .49 \\
\hline$N$ & 2712 & 269 & 2712 & 269 \\
\hline
\end{tabular}




\begin{tabular}{|c|c|c|c|c|}
\hline \multicolumn{5}{|c|}{ Heckman Sample Selection Models of Hospital Legitimacy $(N=269)^{*}$} \\
\hline \multirow[b]{2}{*}{ Independent Variable } & \multicolumn{2}{|c|}{ FTEs/100 Admissionst } & \multicolumn{2}{|c|}{ Return on Equity } \\
\hline & Model 1 & Model 2 & Model 3 & Model 4 \\
\hline Conformity measure 1 & $\begin{array}{r}-.079^{\circ} \\
(.039)\end{array}$ & & $\begin{array}{r}-2.115^{\circ} \\
(.963)\end{array}$ & \\
\hline Conformity measure 2 & & $\begin{array}{c}-.429^{\circ \bullet} \\
(.161)\end{array}$ & & $\begin{array}{c}-9.627^{\bullet} \\
(3.899)\end{array}$ \\
\hline Late adoption & $\begin{array}{r}-.305^{\circ} \\
(.144)\end{array}$ & $\begin{array}{r}-.339^{\circ} \\
(.144)\end{array}$ & $\begin{array}{r}-8.363^{\circ} \\
(3.533)\end{array}$ & $\begin{array}{r}-8.463^{\circ} \\
(3.491)\end{array}$ \\
\hline Number of beds & $\begin{array}{l}.001^{\bullet} \\
(.0005)\end{array}$ & $\begin{array}{l}.001^{\bullet} \\
(.0005)\end{array}$ & $\begin{array}{c}.013 \\
(.013)\end{array}$ & $\begin{array}{c}.013 \\
(.013)\end{array}$ \\
\hline Competition & $\begin{array}{c}.012 \\
(.060)\end{array}$ & $\begin{array}{c}.015 \\
(.061)\end{array}$ & $\begin{array}{c}1.272 \\
(1.465)\end{array}$ & $\begin{array}{c}1.368 \\
(1.465)\end{array}$ \\
\hline Technological sophistication & $\begin{array}{l}.098 \\
(.054)\end{array}$ & $\begin{array}{l}.104 \\
(.055)\end{array}$ & $\begin{array}{c}2.609 \\
(1.327)\end{array}$ & $\begin{array}{c}2.605 \\
(1.336)\end{array}$ \\
\hline Prior return on equity & $\begin{array}{l}.009^{\circ} \\
(.004)\end{array}$ & $\begin{array}{l}.009^{\circ} \\
(.004)\end{array}$ & $\begin{array}{l}.322^{\circ} \\
(.086)\end{array}$ & $\begin{array}{l}.347^{\circ} \bullet \\
(.093)\end{array}$ \\
\hline Prior \% admin. expenses & $\begin{array}{c}-.032 \\
(.027)\end{array}$ & $\begin{array}{c}-.032 \\
(.027)\end{array}$ & $\begin{array}{r}-1.114 \\
(.657)\end{array}$ & $\begin{array}{r}-1.020 \\
(.655)\end{array}$ \\
\hline Prior FTEs/100 admissionst & $\begin{array}{l}.559^{\circ \cdots} \\
(.060)\end{array}$ & $\begin{array}{l}.562^{\circ \cdots} \\
(.060)\end{array}$ & $\begin{array}{c}-2.858 \\
(1.459)\end{array}$ & $\begin{array}{c}-2.731 \\
(1.455)\end{array}$ \\
\hline Prior case mix expense per day & $\begin{array}{c}-.0005 \\
(.0006)\end{array}$ & $\begin{array}{r}-.0005 \\
(.0006)\end{array}$ & $\begin{array}{r}-.019 \\
(.014)\end{array}$ & $\begin{array}{c}-.018 \\
(.014)\end{array}$ \\
\hline Prior debt service coverage ratio & $\begin{array}{c}.070 \\
(.040)\end{array}$ & $\begin{array}{c}.070 \\
(.040)\end{array}$ & $\begin{array}{c}1.028 \\
(1.009)\end{array}$ & $\begin{array}{c}1.029 \\
(1.009)\end{array}$ \\
\hline Constant & $\begin{array}{c}2.457^{\circ \cdots} \\
(.708)\end{array}$ & $\begin{array}{l}2.978^{\bullet \bullet} \\
(.671)\end{array}$ & $\begin{array}{c}2.547^{\circ} \cdot \bullet \\
(.761)\end{array}$ & $\begin{array}{c}2.797^{\circ} \bullet \\
(.749)\end{array}$ \\
\hline Chi-square & $123.72^{\circ} \bullet$ & $118.20^{\circ}$ & $114.34^{\circ}$ & $107.72^{\bullet \bullet}$ \\
\hline Pseudo $R$-square & 61 & .59 & .57 & .54 \\
\hline Rho $(\rho)$ & .49 & .49 & .45 & .46 \\
\hline
\end{tabular}

$\bullet p \leq .05 ; \cdots p \leq .01 ; \cdots p \leq .001 ; t$-tests are one-tailed for hypothesized effects, two-tailed for control variables.

* Unstandardized coefficients are reported; standard errors are in parentheses.

t Values for this measure are subtracted from the highest value in the sample so that higher values reflect greater productivity.

tion. The results are also not driven by universal mandates imposed by large systems on their members. Separate analyses showed that, when the system tie variable was set to zero for members of either of the two largest systems or for members of the five largest systems, the results were substantively unchanged. Finally, given that states have not mandated the adoption of TOM practices, the results also cannot be an artifact of common location in particular states.

The results for models 2 and 4 in Table 2 indicate that the hypothesized effects remain significant after controlling for prior hospital profitability (return on assets), productivity (FTEs/100 admissions), slack (percent administrative expenses), liquidity (debt service coverage ratio), and cost control (case mix expense per day).

Table 3 provides results for the Heckman selection model of hospital legitimacy. The results for models 1 and 3 show that, consistent with hypothesis 4 , both measures of conformity in TQM adoption are positively associated with hospital legitimacy. Although time of adoption has a strong effect on legitimacy when conformity is excluded from the models ( $p<.0001$, not displayed), this relationship disappears when either measure of conformity is added, as indicated by the results in Table 3 . This suggests that the relationship between time of adoption and legitimacy is largely

386/ASQ, June 1997 
mediated by conformity to the normative pattern of implementation (Baron and Kenny, 1986). The effect of conformity on legitimacy remains strongly significant after including additional control variables in models 2 and 4 . Neither profitability nor productivity is significantly related to legitimacy for hospitals in this sample.

Results for Heckman selection models of hospital efficiency are provided in Tables 4 and 5. Models using the survey measure of efficiency are provided in Table 4, and models using the two archival measures are provided in Table 5. The results furnish consistent support for hypothesis 5: conformity to normative TQM adoption is significantly and negatively related to hospital efficiency, for both measures of conformity and all three measures of efficiency. This effect remains significant after controlling for prior performance and other organizational characteristics. Given that the results hold for archival measures of performance, as well as the survey measure, they cannot be attributed to response biases (e.g., variation in enthusiasm for TQM among the respondents) that might be related to conformity in adoption.

\section{DISCUSSION AND CONCLUSIONS}

The results provide strong support for the proposed theoretical framework on the adoption of administrative innovations. In comparison to early adopters, later adopters of TQM programs conformed more closely to the normative pattern of quality practices introduced by other adopting hospitals. This result extends prior research on institutionalization by demonstrating increased conformity over time in the form or definition of innovation adoption, rather than in the overall decision to adopt. The findings are consistent with the view that early adopters, motivated by technical efficiency gains from adoption (Tolbert and Zucker, 1983), are more likely to customize quality practices to the organization's unique needs and capabilities. In contrast, later adopters, experiencing normative pressure to adopt legitimate quality practices, appear more likely to mimic the normative model or definition of TQM adoption implemented in other hospitals. In this way, external social pressures have contributed to isomorphism in the form of TQM programs (Scott, 1987; cf. DiMaggio and Powell, 1983; Zucker, 1983).

The second set of findings, which address the impact of social network ties on institutionalization, provided consistent evidence for a contingent network effect in the form and consequences of innovation adoption. Network ties decreased conformity to normative TQM adoption for early adopters and increased conformity for late adopters. Moreover, this pattern of results held for two different kinds of social network tie: common membership in a strategic alliance and membership in the same hospital system.

While several studies have established that network ties to adopters can increase the likelihood of adopting discrete innovations (e.g., Becker, 1970; Burns and Wholey, 1993; Palmer, Jennings, and Zhou, 1993), theorists have offered divergent and seemingly conflicting interpretations of such findings, variously attributing network effects to vicarious learning driven by efficiency imperatives (e.g., Mansfield, 1971) or, more recently, to mimetic isomorphism (e.g., Palmer, Jennings, and Zhou, 1993). By showing how net- 
work processes may be moderated by the degree of institutionalization, our study may help reconcile these different perspectives. Our findings suggest that in the early stages of the institutionalization process, when institutional forces are limited, social network ties may facilitate "a match between technology and organization" (Levitt and March, 1988: 330) by helping decision makers identify which specific TQM practices exploit the focal organization's distinctive capabilities and resources and which practices promote the hospital's strategic objectives. By contrast, the findings also indicate that at later stages of the institutionalization process, network ties to other adopters facilitate conformity rather than customization of TQM adoption. It appears, consistent with both institutional and network perspectives, that social networks expedite mimetic isomorphism by disseminating knowledge about the normative form of TQM adoption as it emerges over time. Thus, the results may have important implications for the literature on interorganizational networks, which has viewed network effects as unchanging over time (Burkhardt and Brass, 1990, is an important exception).

The third set of results pertained to the organizational consequences of relative conformity in TQM adoption. Consistent with our hypotheses, conformity to normative TQM adoption was negatively associated with organizational efficiency benefits (across three different measures of efficiency) and positively associated with organizational legitimacy benefits from adoption. Relative conformity largely mediated the effect of time of adoption on legitimacy and efficiency, such that early versus late adoption affected hospital outcomes largely through its effect on conformity. While early adopters, recognizing greater opportunity for efficiency gains and free from isomorphic pressures, enjoy greater technical benefits from TQM by customizing quality practices to their organization's unique capabilities and needs, later adopters trade organizational efficiency benefits for legitimacy benefits by conforming to isomorphic pressures. While prior empirical research has not directly examined both the social and economic consequences of institutional processes, the present finding is consistent with recent studies in the organizational impression management literature suggesting that displays of conformity to institutional norms can yield significant legitimacy benefits (D'Aunno, Sutton, and Price, 1991; Elsbach, 1994). By demonstrating how conformity can enhance legitimacy, despite costs to efficiency, the present study provides strong evidence for the independent effect of institutional processes on organizational outcomes. The findings illustrate how an institutional framework that incorporates both legitimacy and performance consequences can explain why organizations would adopt practices that no longer yield competitive advantage.

The findings also extend Edelman's (1992) research on the adoption of affirmative action offices, which inferred conformity to institutional norms from the adoption of more elaborate affirmative action structures, by actually measuring conformity to normative forms of adoption. Our findings also suggest that conformity does not necessarily imply greater structural complexity. The total number of quality practices introduced by later TQM adopters was not more than the

388/ASQ, June 1997 
number introduced by early adopters. Thus, while institutionalization did not lead to greater structural complexity, it did lead to greater conformity.

This study contributes to the nascent empirical literature examining organizational consequences of TOM. Our findings suggest that recent theory and research in this area (e.g., Reger et al., 1994; Powell, 1995a) may have underspecified the organizational consequences of TQM by focusing exclusively on technical performance benefits and paying scant attention to differences between early and late adopters. The observed tendency for later adopters to trade organizational efficiency benefits for legitimacy benefits from TQM adoption provides an alternative explanation for Powell's (1995a) recent finding that TQM did not yield consistent performance improvements. Although Powell concluded that TQM itself does not generate competitive advantage, it appears that TQM provides different kinds of competitive advantage, depending on the time of adoption and the resultant degree of conformity to norms of implementation. This contrast effect in organizational benefits from TQM between early and late adopters is amplified in hospital systems and alliances, because social network ties facilitate customization for early adopters and conformity for later adopters.

This study raises several questions for future research. While the theoretical framework developed in this study extends prior research on TQM by examining the form of TQM adoption, future research might devote more attention to the process of implementation. For instance, researchers could measure variation across organizations in the time required to implement TQM fully and explore how speed of implementation might affect the consequences of adoption and conformity. Relationships between conformity, legitimacy, and performance may be even stronger among hospitals that implement their TQM programs more quickly.

While this study examines legitimacy benefits derived from the form of TQM adoption, future research might also address the separate question of whether adoption itself creates reputational benefits or costs, especially among early adopters. For instance, adopting hospitals might benefit from pro-innovation biases (Rogers, 1983; Abrahamson, 1991). Alternatively, there is some evidence that innovators are met with skepticism until they can demonstrate efficiency benefits from adoption or until móre organizations adopt (e.g., Carroll and Hannan, 1989). As Blumenthal (1995) has documented, there was some question initially about whether TOM was appropriate for hospitals because of entrenched resistance from doctors and other professionals to any interference from administrators and because hospital organizations are inherently bureaucratic. There was also fairly widespread suspicion that TQM might be used by hospitals as a cover for cost cutting that would reduce the quality of care.

Future empirical research could also extend this study by examining the extent to which our framework can predict the form and consequences of TQM in other contexts. While hospitals face strong legitimacy pressures, such pressures are increasingly being felt in other sectors as well, notably in service industries such as financial services and telecommu- 
nications. Moreover, organizations across many sectors are being subjected to growing external review of their quality practices, as well as increased incentives for participating in external evaluations (Powell, 1995b). In recent years applications for the Malcolm Baldridge Award from manufacturing and service organizations have increased considerably. Several authors have suggested that the growing symbolic value of the Baldridge Award has widely influenced quality practices (Sen, 1991; Powell, 1995b; Puffer and McCarthy, 1996). Most of the award criteria are based on specific quality processes rather than outcomes (United States Department of Commerce, 1994), much like the criteria used by the JCAHO to evaluate hospitals. A primary reason why companies are making greater efforts to qualify for the Baldridge Award is that they face increasing pressure from external stakeholders to demonstrate organizational effectiveness. Useem (1993: 57, 71, 213) has documented how organizational changes, including the introduction of TQM practices, have been influenced strongly by the growing power and activism of large institutional investors. Moreover, companies are also under considerable pressure from customers and suppliers to show due diligence in improving quality (Sen, 1991; Shiba, Graham, and Walden, 1993; Powell, 1995b). Thus, with respect to quality practices in particular, manufacturing and service companies may increasingly experience legitimacy pressures similar to those experienced by hospitals.

Future research might also benefit from adapting theoretical perspectives on the diffusion of fads and fashions to understanding the spread of TQM. There is clearly much overlap between the theoretical mechanisms underlying the diffusion of fads and fashions and those leading to institutionalization (e.g., see DiMaggio and Powell, 1983; Abrahamson, 1991). Both literatures emphasize the role of collective social pressures and social interaction in diffusion (e.g., Smelser, 1962; Blumer, 1969; DiMaggio and Powell, 1983), and a management fad can acquire institutional status to the extent that it becomes taken for granted or socially expected as an element of the organization (Meyer and Rowan, 1977; Zucker, 1983). The literature on fads and fashions could provide unique insights into the diffusion and isomorphism of TQM initiatives, in that it offers a rich analysis of how opinion leaders and gatekeepers, such as the mass media, consulting firms, and business schools, mediate the diffusion process (e.g., Hirsch, 1972; Peterson and Berger, 1975; Abrahamson, 1991, 1996). Such perspectives could usefully supplement the perspective developed in this study and may provide insights into why particular TQM practices acquired external legitimacy as taken-for-granted elements of TOM, while other practices did not.

While the findings of this study showed a transition from customization to conformity in implementation as TQM became institutionalized over time, there may be further stages of institutionalization. One possibility is that TQM may ultimately become deinstitutionalized as poor performance outcomes of later adopters reduce its legitimacy, thus allowing organizations to discard or to customize their programs 
(Oliver, 1992). Alternatively, institutional pressures may persist, but performance problems may ultimately lead organizations to resist them openly (Kraatz and Zajac, 1995). Perhaps a more likely outcome, however, is that the nature of conformity could evolve over time from complete acquiescence to institutional pressures to a more complex form of conformity in which organizations formally adopt normative TQM programs but also customize their actual, informal practices to the unique needs of the organization. Just as interorganizational network ties facilitated customization of TOM programs for early adopters and substantive conformity for later adopters, social networks might ultimately facilitate symbolic decoupling, in which organizations conform to institutional pressures by adopting normative TQM programs at the level of formal policy, while customizing their TQM programs at the level of substantive action.

\section{REFERENCES}

Abrahamson, Eric

1991 "Managerial fads and fashions: The diffusion and rejection of innovations." Academy of Management Review, 16: 586-612.

1996 "Management fashion." Academy of Management Review 21: $254-285$

Abrahamson, Eric, and Lori Rosenkopf

1993 "Institutional and competitive bandwagons: Using mathematical modeling as a tool to explore innovation diffusion." Academy of Management Review, 18: 487-517.

Anderson, John C., Manus Rungtusanatham, and Roger G.

Schroeder

1994 "A theory of quality management underlying the Deming management method." Academy of Management Review 19: 472-509.

Bandura, Albert

1977 Social Learning Theory. Englewood Cliffs, NJ: Prentice-Hall.

Baron, James P., Frank Dobbin, and $P$. Devereaux Jennings

1986 "War and peace: The evolution of modern personnel administration in U.S. industry.' American Journal of Sociology, 92: 250-283.

Baron, Reuben M., and David A. Kenny

1986 "The moderator-mediator variable distinction in social psychological research: Conceptual, strategic, and statistical considerations." Journal of Personality and Social Psychology, 51: 1173-1182.
Barsness, Zoe I., Stephen M. Shortell, Robin R. Gillies, Edward F. Hughes, James L. O'Brien, Deborah Bohr, Christine Izui, and Peter Kralovec

1993 "The quality march." Hospitals and Health Networks, December: $52-55$.

Becker, Marshall $\mathrm{H}$.

1970 "Sociometric location and innovativeness: Reformulation and extension of the diffusion model." American Sociological Review, 35: 262-282.

Berwick, Donald M., A. Blanton

Godfrey, and Jane Roessner

1989 "Continuous improvement as an ideal in health care." New England Journal of Medicine, 320: 53-56.

1990 Curing Health Care. San Francisco: Jossey-Bass.

Beyer, Janice M., Donde P. Ashmos, and Richard N. Osborn

1997 "Contrasts in enacting TQM: Mechanistic vs. organic ideology and implementation." Journal of Quality Management, 2: 3-39.

Blumenthal, David

1995 "Applying industrial quality management science to physicians' clinical decisions." In D. Blumenthal and A. C. Scheck (eds.), Improving Clinical Practice: TQM and the Physician: 25-50. San Francisco: JosseyBass.

Blumer, Herbert G.

1969 "Fashion: From class differentiation to collective selection." Sociological Quarterly, 10: 275-291.
Burkhardt, Marlene E., and Daniel J. Brass

1990 "Changing patterns or patterns of change: The effects of a change in technology on social network structure and power." Administrative Science Quarterly, 35: 104-127.

Burns, Lawton R., and Douglas R. Wholey

1993 "Adoption and abandonment of matrix management programs: Effects of organizational characteristics and interorganizational networks." Academy of Management Journal, 36: 106-138.

Burt, Ronald S.

1987 "Social contagion and innovation: Cohesion versus structural equivalence." American Journal of Sociology, 92: 1287-1335.

Campbell, John L.

1994 "Recent trends in institutional analysis: Bringing culture back into political economy." Working paper, Department of Sociology, Harvard University.

Carroll, Glenn R., and Michael T. Hannan

1989 "Density dependence in the evolution of populations of newspaper organizations." American Sociological Review, 54: 524-541.

Coleman, James S., Elihu Katz, and Herbert Menzel

1966 Medical Innovation: A Diffusion Study. New York: BobbsMerrill.

Crosby, Philip B.

1984 Quality Without Tears: The Art of Hassle-Free Management. Milwaukee, WI: Quality Press. 
Cyert, Richard M., and James G. March

1963 A Behavioral Theory of the Firm. Englewood Cliffs, NJ: Prentice-Hall.

Damanpour, Fariborz

1987 "The adoption of technological, administrative, and ancillary innovations: Impact of organizational factors." Journal of Management, 13: 675688.

D'Aunno, Thomas, Robert I. Sutton, and Richard H. Price

1991 "Isomorphism and external support in conflicting institutional environments: A study of drug abuse treatment units." Academy of Management Journal, 34: 636-661.

Darr, Eric D., Linda Argote, and

Dennis Epple

1995 "The acquisition, . transfer and depreciation of knowledge in service organizations: Productivity in franchises." Management Science, 41: 1750-1762.

Davis, Gerald F.

1991 "Agents without principles? The spread of the poison pill through the intercorporate network." Administrative Science Quarterly, 36: 583-613.

Dean, James W., and Dean E. Bowen

1994 "Management theory and total quality: Improving research and practice through theory development." Academy of Management Review, 19: 392-418.

Deming, W. Edwards

1993 The New Economics for Industry, Government, Education. Cambridge, MA: MIT Center for Advanced Engineering Study.

DiMaggio, Paul J., and Walter W. Powell

1983 "The iron cage revisited: Institutional isomorphism and collective rationality in organizational fields." American Sociological Review, 48: 147160.

Edelman, Lauren B.

1992 "Legal ambiguity and symbolic structures: Organizational mediation of civil rights law." American Journal of Sociology, 97: 1531-1577.

Elsbach, Kimberly D.

1994 "Managing organizational legitimacy in the California cattle industry: The construction and effectiveness of verbal accounts." Administrative Science Quarterly, 39: 57-88.
Fligstein, Neil

1985 "The spread of the multi-divisional form among large firms 1919-1979." American Sociological Review, 50: 377-391.

Galaskiewicz, Joseph, and Stanley Wasserman

1989 "Mimetic processes within an interorganizational field: An empirical test." Administrative Science Quarterly, 34: 454479.

Greer, A.L.

1977 "Advances in the study of diffusion of innovation in health care organizations." Milibank Memorial Fund Quarterly, 55 505-532.

Griffith, John R., V.K. Sahney, and R.A. Mohr

1995 Reengineering Health Care: Building on CQl. Ann Arbor MI: Health Administration Press.

Gulati, Ranjay

1995a "Does familiarity breed trust? The implications of repeated ties for contractual choice in alliances." Academy of Management Journal, 38: 85113.

1995b "Social structure and alliance formation patterns: A longitudinal analysis." Administrative Science Quarterly, 40: 619-652.

Gustafson, David, and Ann F.

Hundt

1995 "Findings of innovation research applied to quality management principles for health care." Health Care Management Review, 20: 16-33.

Hackman, J. Richard, and Ruth Wageman

1995 "Total quality management: Empirical, conceptual, and practical issues." Administrative Science Quarterly, 40: 203-370.

Harrison, J. Richard, and Larry Mitchell

1995 "Interaction effects in quasilinear models." Working paper, School of Management, University of Texas at Dallas.

Haunschild, Pamela R.

1993 "Interorganizational imitation: The impact of interlocks on corporate acquisition activity." Administrative Science Quarterly, 38: 564-592.

Heckman, James

1979 "Sample selection bias as a specification error." Econometrica, 47: 153-161.
Hirsch, Paul M.

1972 "Processing fads and fashions: An organization-set analysis of cultural industry systems." American Journal of Sociology, 77: 639-659.

Huber, George P.

1991 "Organizational learning: The contributing processes and the literatures." Organization Science, 2: 88-115.

Jaccard, James, Robert Turrisi, and Choi K. Wan

1990 Interaction Effects in Multiple Regression. London: Sage.

Jackson, J. Edward

1991 A User's Guide to Principal Components. New York: Wiley.

Johnston, John

1984 Econometric Methods. New York: McGraw-Hill.

Juran, Joseph M.

1989 Juran on Planning for Quality. New York: Free Press.

Kaluzny, Arnold D., Howard S.

Zuckerman, and Thomas C. Ricketts III

1995 Partners for the Dance: Forming Strategic Alliances in Health Care. Chicago: Health Administration Press.

Kimberly, John R., and Michael J. Evanisko

1981 "Organizational innovation:

The influence of individual, organizational, and contextual factors on hospital adoption of technological and administrative innovations." Academy of Management Journal, 24: 689-713.

Kraatz, Matthew S., and Edward J. Zajac

1995 "Exploring the limits of the new institutionalism: The causes and consequences of illegitimate organizational change." American Sociological Review, 61: 812-836.

Laffel, Glen, and David Blumenthal

1989 "The case for using industrial quality management science in health care organizations." Journal of the American Medical Association, 262: 28692873.

Lathrop, J. P.

1993 Restructuring Health Care. San Francisco: Jossey-Bass.

Lawler, Edward E., and Susan A. Mohrman

1985 "Quality circles after the fad." Harvard Business Review, 63 (1): 64-71. 


\section{TQM Adoption}

Levitt, Barbara, and James G. March

1988 "Organizational learning." In Annual Review of Sociology, 14: 319-340. Palo Alto, CA: Annual Reviews.

Maddala, G. S.

1983 Limited-Dependent and Qualitative Variables in Econometrics. Cambridge: Cambridge University Press.

Mansfield, Edwin

1971 Technological Change. New York: W.W. Norton.

Marsden, Peter V., and Noah E. Friedkin

1993 "Network studies of social influence." Sociological Methods and Research, 22: 127151.

McKinney, Martha, Arnold D. Kaluzny, and Howard S. Zuckerman

1991 "Paths and pacemakers: Innovation diffusion networks in multihospital systems and alliances." Health Care Management Review, 16: 17-23.

Meyer, John W., and Brian Rowan

1977 "Institutional organizations: Formal structure as myth and ceremony." American Journal of Sociology, 83: 340-363.

Meyer, John W., W. Richard Scott, and Terrence E. Deal

1983 "Institutional and technical sources of organizational structure: Explaining the structure of educational organizations." In John W. Meyer and W. Richard Scott (eds.), Organizational Environments: Ritual and Rationality: 45-67. Newbury Park, CA: Sage.

Meyer, Marshall, William Stevenson, and Stephen Webster

1985 Limits to Bureaucratic Growth. Berlin: de Gruyter.

Mezias, Stephen J.

1990 "An institutional model of organizational practice: Financial reporting at the Fortune 200." Administrative Science Quarterly, 35: 431-457.

Mizruchi, Mark S.

1992 The Structure of Corporate Political Action: Interfirm Relationships and Their Consequences. Cambridge, MA Harvard University Press.

Mizruchi, Mark S., and Linda Brewster Stearns

1988 "A longitudinal study of the formation of interlocking directorates." Administrative Science Quarterly, 33: 194-210.
Moch, Michael K., and Edward V. Morse

1977 "Size, centralization and organizational adoption of innovations." American Sociological Review, 42: 716-725.

Nohria, Nitin, and Ranjay Gulati

1995 "Is slack good or bad for innovation?" Academy of Management Journal, 39: 1245-1264.

Oliver, Christine

1991 "Strategic responses to institutional processes." Academy of Management Journal, 16: 145-179.

1992 "The antecedents of deinstitutionalization." Organization Studies, 13: 563-588.

Palmer, Donald A., P. Devereaux Jennings, and Xueguang Zhou

1993 "Late adoption of the multidivisional form by large U.S. corporations: Institutional, political, and economic accounts." Administrative Science Quarterly, 38: 100-131.

Peterson, Richard A., and David

G. Berger

1975 "Entrepreneurship in organizations: Evidence from the popular music industry." American Sociological Review 40: 158-173.

Pfeffer, Jeffrey

1981 "Management as symbolic action: The creation and maintenance of organizational paradigms." In L.L. Cummings and Barry M. Staw (eds.), Research in Organizational Behavior, 3: 1-52. Greenwich, CT: JAI Press.

Powell, Thomas C.

1995a "Total quality management as competitive advantage: $A$ review and empirical study." Strategic Management Journal, 16: 15-37.

$1995 b$ "When lemmings learn to sail: Turning TQM to competitive advantage." In B. Voss and D. Wiley (eds.), 1995 Handbook of Business Strategy: 42-54. Washington, DC: Faulkner \& Gray.

Puffer, Sheila M., and Daniel J. McCarthy

1996 "A framework for leadership in a TQM context." Journal of Quality Management, 1: 109130.

Reed, Richard, David J. Lemak and Joseph C. Montgomery 1996 "Beyond process: TQM content and firm performance." Academy of Management Review, 21: 173-202.
Reger, Rhonda K., Loren T. Gustafson, Samuel M. Demarie, and John V. Mullane

1994 "Reframing the organization: Why implementing total quality is easier said than done." Academy of Management Review, 19: 565-584.

Rogers, Everett M.

1983 Diffusion of Innovations. New York: Free Press.

Rosner, Menahem $\mathrm{M}$.

1968 "Economic determinants of organizational innovation." Administrative Science Quarterly 12: 614-625.

Scott, W. Richard

1987 "The adolescence of institutional theory." Administrative Science Quarterly, 32: 493511.

1995 Institutions and Organizations. Thousand Oaks, CA: Sage.

Scott, W. Richard, and John W. Meyer

1983 "Environmental linkages and organizational complexity: Public and private schools." In H.M. Levin and T. James (eds.), Comparing Public and Private Schools: 128-160. New York: Fulmer

Sen, Tapas

1991 "Commentary." In Thomas A. Kochan and Michael Useem (eds.), Transforming Organizations: 186-187. New York: Oxford University Press.

Senge, Peter $M$.

1990 The Fifth Discipline. New York: Doubleday Currency.

Shan, Weijan, Gordon Walker, and Bruce Kogut

1994 "Interfirm cooperation and startup innovation in the biotechnology industry." Strategic Management Journal, 15: 387-394.

Shiba, Shoji, Alan Graham, and David Walden

1993 A New American TQM: Four Practical Revolutions in Management. Portland, OR: Revolutionary Press.

Shortell, Stephen M., James L. $\mathrm{O}^{\prime}$ Brien, and James M. Carman

1995 "Assessing the impact of continuous quality improvement/ total quality management: Concept versus implementation." Health Services Research, 30: 377-401.

Smelser, Neil

1962 Theory of Collective Behavior. New York: Free Press. 
Tolbert, Pamela S., and Lynne G. Zucker

1983 "Institutional sources of change in the formal structure of organizations: The diffusion of civil service reform, 18801935." Administrative Science Quarterly, 28: 22-39.

Tushman, Michael L.

1977 "Communication across organizational boundaries: Special boundary roles in the innovation process." Administrative Science Quarterly, 22: 587605.

United States Department of Commerce

1994 Award Criteria, Malcolm Baldridge National Quality Award. Washington, DC: United States Department of Commerce, National Institute of Standards and Technology.

Useem, Michael

1993 Executive Defense: Shareholder Power and Corporate Reorganization. Cambridge, MA: Harvard University Press.

van de Ven, Wynand P.M.M., and Bernard M.S. van Praag

1981 "The demand for deductibles in private health insurance." Journal of Econometrics, 17: 229-252.
Waldman, David A.

1994 "The contributions of total quality management to a theory of work performance." Academy of Management Review, 19: 510-536.

Westphal, James, and Edward J.

Zajac

1994 "Substance and symbolism in CEOs' long-term incentive plans." Administrative Science Quarterly, 39: 367-390.

1997 "Defections from the inner circle: Social exchange, reciprocity and the diffusion of board independence in U.S. corporations." Administrative Science Quarterly, 42: 161183.

Williams, Frederick, and David V. Gibson

1990 Technology Transfer: A Communication Perspective. London: Sage.

Zajac, Edward J., and James D. Westphal

1995 "Accounting for the explanations of CEO compensation: Substance and symbolism." 40: 283-308.
Zaltman, Gerald, Robert Duncan, and Jonny Holbek

1973 Innovations and Organizations. New York: Wiley.

Zenger, Todd R., and Barbara S. Lawrence

1989 "Organizational demography: The differential effects of age and tenure distributions on technical communication." Academy of Management Journal, 32: 353-376.

Ziegenfuss, John T.

1993 The Organization's Path to Health Care Quality. Chicago: American College of Health Care Executives.

Zucker, Lynne G.

1977 "The role of institutionalization in cultural persistence." American Sociological Review, 42: 726-743.

1983 "Organizations as institutions." In Samuel B. Bacharach (ed.), Research in the Sociology of Organizations, 2: 1-42. Greenwich, CT: JAI Press.

\section{APPENDIX: Total Quality Practices Survey Items}

1. Periodic assessment of community needs.

2. Benchmarking (i.e., comparing) quality improvement results against those of other health care organizations.

3. Formation of project teams to improve quality.

4. Reporting of results by project teams to improve quality.

5. Formation of a Quality Improvement Council or Steering Committee.

6. Senior management training in TQM principles and methods.

7. Middle management training in TQM principles and methods.

8. Physician training in TOM principles and methods.

9. Overall review and evaluation of our approach to improving quality.

10. Incorporation of TQM criteria into the reward and performance appraisal system.

11. Use of nominal group methods.

12. Use of brainstorming.

13. Use of pareto diagrams.

14. Use of cause and effect ("Fishbone") diagrams.

15. Use of control charts.

16. Use of run charts.

17. Use of histograms.

18. Use of scatter diagrams.

19. Use of process flow charts.

20. Use of affinity diagrams. 